Jurnal Info Kesehatan

Vol 16, No.2, Desember 2018, pp. 226-235

P-ISSN 0216-504X, E-ISSN 2620-536X

Journal DOI: https://doi.org/10.31965/infokes

Website: http://jurnal.poltekeskupang.ac.id/index.php/infokes

RES E A R C H

Open Access

\title{
Hubungan Senam Hamil Dengan Detak Jantung Janin Pada Ibu Hamil Di Wilayah Kerja Puskesmas Kereng Bangkirai Kota Palangkaraya
}

\author{
Eline Charla Sabatina Bingan \\ Kebidanan, Poltekkes Palangka Raya, Jalan George Obos No. 30/ 32, Palangka Raya - 73111 \\ Telp/Fax: (0536) 3221768, 3230730 \\ email: elinbingan@yahoo.com, elinecarlabingan@gmail.com
}

\begin{abstract}
Abstrak
Latar Belakang: Senam hamil merupakan salah satu usaha menjaga kesehatan ibu hamil dan janin, jika ibu hamil rutin melakukan senam hamil secara teratur akan mempengaruhi peningkatan hormon dan sistem saraf otonom yang mempengaruhi detak jantung janin pada ibu hamil. Kegiatan senam hamil juga memberikan efek yang baik bagi sistem kardiovaskular dengan senan hamil ibu memberikan respon yang baik bagi janin. Tujuan: Penelitian ini bertujuan untuk mengetahui hubungan senam hamil dengan detak jantung janin pada ibu hamil yang melakukan senam hamil. Mengetahui rerata detak jantung janin pada ibu senam hamil dan yang tidak senam hamil. Metode: Penelitian ini menggunakan Analitik Observasional dengan desain Kohort yaitu penelitian epidemiologis non-eksperimental. Sampel pada penelitian ini berjumlah $32 \mathrm{ibu}$ hamil yang dibagi menjadi 2 kelompok yaitu 16 ibu hamil mengikuti senam hamil dan 16 ibu hamil tidak mengikuti senam hamil. Hasil: Berdasarkan hasil dari uji T test didapatkan hasil bahwa nilai p-value 0,000 $(<0,05)$ dan ratarata detak jantung janin pada kelompok ibu hamil yang mengikuti senam hamil yaitu 144,94 dan rata- rata detak jantung janin pada kelompok ibu hamil yang tidak mengikuti senam hamil yaitu 157,56. Kesimpulan: Berdasarkan hasil penelitian dapat disimpulkan ada hubungan senam hamil dengan detak jantung janin pada ibu hamil yang melakukan senam hamil. Ada perbedaan detak jantung janin pada ibu hamil yang mengikuti senam hamil dan ibu hamil yang tidak mengikuti senam hamil.
\end{abstract}

Kata Kunci : Senam hamil, Detak jantung janin 


\title{
Pregnancy Relationship With Fetal Health Principles In Pregnant Woman In The Working Region Puskesmas Kereng Bangkirai Kota Palangkaraya
}

\begin{abstract}
Background: Gymnastics pregnancy is one effort to maintain the health of pregnant and fetal mothers, if pregnant women routinely perform pregnancy exercise regularly will affect the increase in hormones and autonomic nervous system that affect the fetal heart rate in pregnant women. Pregnancy gymnastics activities also provide a good effect for the cardiovascular system with maternity pregnant women provide a good response to the fetus. Purpose: This study aims to determine the relationship of pregnancy exercise with fetal heart rate in pregnant women who do gymnastics pregnant. Know the rate of fetal heart rate in pregnant and non-pregnancy exercise mothers. Method: This study used Observational Analytic with Cohort design that is non-experimental epidemiological research. Samples in this study amounted to 32 pregnant women who were divided into 2 groups of 16 pregnant women following pregnancy exercise and 16 pregnant women did not follow pregnancy exercise. Result: Based on the result of $T$ test, it was found that p-value $0.000(<0,05)$ and mean fetal heart rate in pregnant women's group that is 144,94 and mean fetal heart rate in group pregnant women who do not follow pregnancy exercise is 157,56 . Conclusion: Based on the research results can be concluded there is relationship pregnancy gymnastics with fetal heart rate in pregnant mother doing pregnant exercise.There are differences in fetal heart rate in pregnant women who follow pregnancy exercise and pregnant women who do not follow pregnancy exercises.
\end{abstract}

Keywords: Gymnastics pregnant, Fetal heartbeat

\footnotetext{
* Correspondence: elinbingan@yahoo.com

Present Address: 30/32, George Obos St., Palangka Raya - Indonesia, 73111 Telp/Fax: (0536) 3221768, 3230730

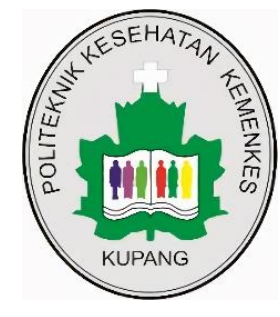

CThe Author(s) 2018. This article is distributed under the terms of the Creative Commons Attribution 4.0 International License (http://creativecommons.org/licenses/by/4.0/), which permits unrestricted use, distribution, and reproduction in any medium, provided you give appropriate credit to the original author(s) and the source, provide a link to the Creative Commons license, and indicate if changes were made. The Creative Commons Public Domain Dedication waiver (http://creativecommons.org/publicdomain/zero/1.0/) applies to the data made available in this article, unless otherwise stated.
} 


\section{PENDAHULUAN}

Kehamilan merupakan pertumbuhan dan perkembangan janin intrauterin mulai sejak konsepsi dan berakhirnya sampai permulaan persalinan. Masa kehamilan normal 280 hari (40 minggu atau 9 bulan 7 hari) dihitung dari hari haid terakhir. Kehamilan di bagi menjadi 3 trimester yaitu, trimester pertama dimulai dari hasil konsepsi sampai 3 bulan, trimester kedua dari bulan ke 4 sampai bulan ke 6 , dan trimester ketiga dari bulan ke 7 sampai bulan ke 9. ${ }^{1}$

Namun dalam prosesnya dapat terjadi berbagai masalah yang dapat yang dapat membahayakan ibu dan janin. Masalah yang dihadapi dapat berupa masalah ringan yang merupakan akibat dari perubahan fisiologis ibu hamil hingga masalah yang berat yang menjadi komplikasi kehamilan. Masalah yang dihadapi oleh ibu hamil dapat terjadi dalam setiap masa kehamilan dari trimester I hingga trimester III. $^{2}$ Ibu hamil diwajibkan untuk melakukan kunjungan ANC minimal 4 kali pada masa kehamilan bertujuan untuk mengetahui kesehatan ibu dan janin.

Menurut data WHO, jumlah kematian janin dalam kandungan didunia mencapai 12 per 1.000 kelahiran hidup. Wilayah Asia Tenggara angka kematian janin dalam kandungan mencapai 22 per 1.000 kelahiran hidup. Di Indonesia angka kematian bayi 27 per 1.000 kelahiran hidup ini menunjukkan bahwa angka kematian bayi di Indonesia masih tinggi dari negara ASEAN lainnya, jika dibandingkan dengan target MDGs (Millenium Development Goals) tahun 2015 yaitu 23 per 1000 kelahiran hidup. ${ }^{3}$ Menurut Dinas Kesehatan Kota Palangka Raya tahun 2015 angka kasus kematian janin di dalam kandungan atau tidak terdeteksinya detak jantung janin sebanyak 67 kasus. Salah satu penyebab kematian janin adalah tidak terdeteksinya detak jantung janin. Bayi yang lahir dalam keadaan meninggal 93\% nya dikarenakan kelainan detak jantung janin yang dikarenakan kekurangan oksigen yang diberikan oleh ibu kepada janin melalui plasenta yang disebut Hipoksia. Tanda terjadinya hipoksia antara lain terjadinya bradikardia, hipotensi, turunnya curah jantung dan gangguan metabolik seperti respiratorius.

Selain kejadian hipoksia, kelainan detak jantung janin berupa takikardi dapat terjadi pada bayi yang lahir dalam keadaan prematur. Bayi yang prematur cenderung mempunyai DJJ yang lebih tinggi karena keterlambatan maturitas saraf parasimpatis. ${ }^{4}$ Senam hamil menjadi salah satu usaha untuk menjaga kesehatan ibu hamil, mengurangi stress akibat cemas menjelang persalinan. Oleh karena itu, senam hamil berperan dalam mempersiapkan proses persalinan dan membuat tubuh ibu menjadi sehat dan bugar sehingga ibu dapat menjalankan aktivitas sehari-hari.

Penelitian terbaru yang dilakukan menunjukkan bahwa senam hamil 
memiliki pengaruh positif terhadap pertumbuhan dan perkembangan janin didalam kandungan. Sekitar 10 menit melakukan latihan teratur akan meningkatkan detak jantung janin dan akan terus meningkat seiring dengan olahraga yang dilakukan sang ibu. Ini adalah respon normal dan tidak membahayakan janin. ${ }^{5}$

Selain itu, ada penelitian yang menjelaskan mengenai efek latihan senam hamil terhadap detak jantung janin yang melibatkan 61 ibu hamil yang sehat berusia 21-35 tahun. $50 \%$ ibu hamil diminta untuk melakukan senam hamil, sisanya tidak melakukan senam hamil. Ibu hamil diminta untuk melakukan senam hamil minimal 4 kali dan pada minggu ke 4 didapatkan hasil yaitu detak jantung janin yang sangat aktif adalah $136 \mathrm{x} /$ menit pada kelompok yang melakukan senam hamil dan 148 $\mathrm{x} /$ menit pada kelompok yang tidak melakukan senam hamil. Hal ini menunjukkan detak jantung janin lebih rendah atau normal pada ibu yang rutin melakukan senam hamil. Jantung akan bertambah kuat jika dilatih dan jika jantung sudah lebih kuat, detak jantung akan turun. ${ }^{6}$

Maka jantung tidak perlu bekerja terlalu keras untuk memompa jumlah darah yang sama. Sampai saat ini masih sedikit penelitian dan informasi ilmiah tentang senam hamil. Di Kota Palangka Raya sendiri telah ada beberapa puskesmas yang mengadakan kegiatan senam hamil seperti di Puskesmas Bukit Hindu, Puskesmas Kayon, Puskesmas Menteng, Puskesmas Pahandut, dan Puskesmas Kereng Bangkirai namun kegiatan tersebut masih kurang di evaluasi terutama manfaat senam hamil untuk detak jantung janin.

Di Puskesmas Kereng Bangkirai sendiri mempunyai jumlah target kunjungan ibu hamil yang tinggi tetapi meskipun jumlah kunjungan ibu hamil tinggi masih banyak ibu hamil yang tidak mengikuti kegiatan senam hamil. Ibu hamil hanya datang untuk periksa saja. Pada tahun 2016 jumlah ibu hamil yang melakukan kunjungan ANC berjumlah 144 orang dan yang mengikuti kelas hamil berjumlah 58 orang, pada tahun 2017 jumlah ibu hamil yang melakukan kunjungan ANC berjumlah 152 orang dan yang mengikuti kelas hamil berjumlah 44 orang. Ini membuktikan adanya kegiatan kelas hamil di masyarakat masih belum terlalu diminati oleh ibu hamil.

Dari latar belakang penelitian diatas, peneliti tertarik untuk meneliti pengaruh senam hamil terhadap detak jantung janin pada ibu hamil.

\section{METODE PENELITIAN}

Penelitian ini menggunakan Analitik Observasional dengan desain Kohort yaitu penelitian epidemiologis non-eksperimental yang digunakan untuk mempelajari hubungan antara 
faktor risiko (variabel independen) berdasarkan uji hipotesis beda rata-rata dengan efek kejadian (variabel dan setiap kelompok intervensi dan dependen). Studi kohort merupakan kelompok kontrol jika terjadi drop out penelitian yang didasarkan pada maka akan ditambah 2 ibu hamil yang pengamatan sekelompok tertentu dalam memenuhi kriteria insklusi. jangka waktu tertentu. Dalam hal ini, kelompok yang diamati merupakan kelompok dengan 2 kategori tertentu yaitu yang terpapar dan yang tidak terpapar terhadap faktor yang dicurigai sebagai faktor penyebab.

Populasi dalam penelitian ini adalah ibu hamil yang mengikuti kelas ibu hamil di Wilayah Kerja Puskesmas Kereng Bangkirai Kota Palangka Raya. Jumlah sampel pada penelitian ini Teknik pengambilan sampel yang digunakan pada penelitian ini adalah Nonpropability sampling dengan jenis purposive sampling yaitu cara pengambilan sampel berdasarkan penilaian peneliti mengenai siapa saja yang pantas memenuhi persyaratan untuk dijadikan sampel atau teknik pengambilan sampling yang dilakukan dengan pertimbangan tertentu sesuai ciri-ciri yang dikehendaki. ${ }^{7}$

diperoleh dengan rumus sampel

HASIL DAN ANALISIS

A. Analisis Univariat

1. Karakteristik Responden

a) Senam Hamil

Tabel 1. Distribusi Responden Senam Hamil

\begin{tabular}{lcc}
\hline Senam Hamil & Frekuensi & Presentase \\
\cline { 2 - 3 } & $\mathbf{N}$ & $\mathbf{\%}$ \\
\hline Senam Hamil & 16 & 50,0 \\
Tidak Senam & 16 & 50,0 \\
\hline Total & 32 & 100 \\
\hline
\end{tabular}

Berdasarkan tabel diatas menunjukkan ibu hamil yang menjadi mengikuti senam hamil 16 responden $(50,0 \%)$ dan ibu hamil yang tidak mengikuti senam hamil 16 responden $(50,0 \%)$.

b) Usia Kehamilan

Tabel 2. Distribusi Responden Usia Kehamilan

\begin{tabular}{ccccc}
\hline Variabel & Mininum & Maxinum & Mean & $\begin{array}{c}\text { Standar } \\
\text { Deviasi }\end{array}$ \\
\hline $\begin{array}{c}\text { Usia } \\
\text { Kehamilan }\end{array}$ & 28 & 33 & 30,91 & 1,729 \\
\hline
\end{tabular}


Berdasarkan tabel diatas, menunjukkan mininum usia kehamilan pada penelitian yaitu 28 minggu dan usia kehamilan maxinum 33 minggu. Rata- rata usia kehamilan pada penelitian yaitu 30,91 dan standar deviasi 1,729.

c) Usia Ibu Hamil

Tabel 3. Distibusi Responden Usia Ibu Hamil

\begin{tabular}{ccccc}
\hline Variabel & Mininum & Maxinum & Mean & $\begin{array}{c}\text { Standar } \\
\text { Deviasi }\end{array}$ \\
\hline Usia & 17 & 42 & 29,91 & 6,156 \\
\hline
\end{tabular}

Berdasarkan tabel diatas, menunjukkan mininum usia ibu hamil yang menjadi responden pada penelitian yaitu 17 tahun dan usia maxinum 42 tahun. Rata- rata usia ibu hamil yang menjadi responden yaitu \pm 30 tahun dan standar deviasi 6,156.

d) Pendidikan Ibu Hamil

Tabel 4. Distribusi Pendidikan Ibu Hamil

\begin{tabular}{lcc}
\hline Pendidikan & Frekuensi & Presentase \\
\cline { 2 - 3 } & $\mathrm{N}$ & $\%$ \\
SD & 8 & 25,0 \\
SMP & 10 & 31,3 \\
SMA & 14 & 43,8 \\
\hline Total & 32 & 100 \\
\hline
\end{tabular}

Berdasarkan tabel diatas, menunjukan pendidikan terakhir ibu hamil yang menjadi responden penelitian yaitu SD 25,0\%, SMP 31,3\% dan SMA 43,8\%. Paling tinggi pendidikan terakhir ibu hamil yang menjadi responden yaitu SMA berjumlah 14 responden dan paling rendah pendidikan terakhir ibu hamil yaitu SD berjumlah 8 responden.

e) Pekerjaan

Tabel 5. Distribusi Responden Pekerjaan Ibu Hamil

\begin{tabular}{lcc}
\hline Pekerjaan & Frekuensi & Presentase \\
\cline { 2 - 3 } & $\mathbf{N}$ & $\mathbf{\%}$ \\
\hline Bekerja & 13 & 40,6 \\
Tidak Bekerja & 19 & 59,4 \\
\hline Total & 32 & 100 \\
\hline
\end{tabular}


Berdasarkan tabel diatas menunjukkan ibu hamil yang menjadi responden penelitian 13 responden bekerja (40,6\%) dan 19 responden penelitian tidak bekerja $59,4 \%$.

f) Karakteristik Detak Jantung Janin Pada Ibu Hamil

Tabel 6. Distribusi Detak Jantung Janin Pada Ibu Hamil

\begin{tabular}{ccccc}
\hline Variabel & Mininum & Maxinum & Mean & Standar Deviasi \\
\hline DJJ & 136 & 160 & 151,25 & 7,746 \\
\hline
\end{tabular}

Berdasarkan tabel diatas, menunjukkan detak jantung janin (DJJ) minimum pada kelompok ibu hamil yaitu 136x/menit, dan detak jantung janin (DJJ) maksinum pada kelompok ibu hamil yaitu 160x/menit. Rata-rata detak jantung janin (DJJ) pada kelompok ibu hamil yaitu 151x/menit dan Standar Deviasi 7,746.

B. Analisis Bivariat

1. Pengaruh Senam Hamil Terhadap Detak Jantung Janin

Tabel 7. Pengaruh Senam Hamil Terhadap Detak Jantung Janin

\begin{tabular}{ccccc}
\hline $\begin{array}{c}\text { Senam } \\
\text { Hamil }\end{array}$ & N & Mean DJJ & SD & $\boldsymbol{p}$-Value \\
\hline Ya & 16 & 144,94 & 5,567 & 0,000 \\
Tidak & 16 & 157,56 & 2,828 & \\
\hline
\end{tabular}

Hasil dari uji $\mathrm{T}$ test didapatkan nilai rata-rata detak jantung janin pada kelompok ibu hamil yang mengikuti senam hamil yaitu $145 \mathrm{x} /$ menit dan rata-rata detak jantung janin pada ibu hamil yang tidak mengikuti senam hamil yaitu $157 \mathrm{x} /$ menit. Hasil uji statistik didapatkan nilai $p$-value 0,000 $(<0,05)$. Oleh karena itu, dapat disimpulkan ada hubungan senam hamil dengan detak jantung janin.

\section{Pembahasan}

1. Karakteristik responden

Berdasarkan hasil analisis yang dilakukan oleh peneliti, ibu hamil yang mengikuti senam hamil sebanyak 4 kali yaitu berjumlah 16 responden dan ibu hamil yang tidak mengikuti senam hamil berjumlah 16 responden.
Berdasarkan hasil analisis yang dilakukan oleh peneliti, umur ibu hamil yang menjadi responden penelitian yang termuda yaitu umur 17 tahun dan usia ibu hamil yang menjadi responden penelitian yang tertua yaitu 42 tahun. Rata-rata usia ibu hamil pada penelitian ini yaitu \pm 30 tahun. 
Berdasarkan hasil analisis yang dilakukan oleh peneliti minimum usia kehamilan pada penelitian ini yaitu usia kehamilan 28 minggu dan dan usia kehamilan maxinum 33 minggu. Ratarata usia kehamilan pada penelitian yaitu 30,91 .

Berdasarkan hasil analisis yang dilakukan oleh peneliti, pendidikan terakhir ibu hamil yang menjadi responden pada penelitian ini yaitu 43,8\% SMA, 31,3\% SMP dan 25,0\% SD. Pendidikan terakhir ibu hamil yang tertinggi yaitu SMA dan pendidikan terakhir ibu terendah yaitu SD.

Berdasarkan hasil analisis yang dilakukan oleh peneliti, ibu hamil menjadi responden pada penelitian ini $59,4 \%$ tidak bekerja (IRT) dan 40,6\% bekerja (berdagang). Hal ini menunjukkan ibu hamil yang menjadi responden penelitian sebagai besar tidak bekerja atau dapat dikatakan sebagai ibu rumah tangga.

Berdasarkan hasil analisis yang dilakukan oleh peneliti detak jantung janin minimun yaitu 136x/menit dan maxinum 160xmenit. Rata-rata detak jantung janin (DJJ) pada kelompok ibu hamil yaitu 151x/menit dan Standar Deviasi 7,746.

\section{Pengaruh Senam Hamil} Terhadap Detak Jantung Janin Berdasarkan analisis didapatkan rata-rata detak jantung janin pada ibu hamil yaitu 151x/menit. Hasil dari uji T test didapatkan nilai rata-rata detak jantung janin pada kelompok ibu hamil yang mengikuti senam hamil yaitu $145 \mathrm{x} /$ menit dan rata-rata detak jantung janin pada kelompok ibu hamil yang tidak mengikuti senam hamil yaitu $157 \mathrm{x} /$ menit. Didapatkan nilai $p$-value $0,000(<0,05)$. Oleh karena itu, dapat disimpulkan ada pengaruh senam hamil dengan detak jantung janin.

Hasil penelitian ini juga sejalan dengan penelitian sebelumnya yang menyatakan bahwa pengaruh pemberian senam hamil pada ibu hamil dengan detak jantung janin di wilayah kerja Puskesmas Kuta Baro Aceh Besar dengan jumlah sampel $30 \mathrm{ibu}$ hamil yang dibagi menjadi kelompok kontrol dan kelompok intervensi. Hasilnya detak jantung janin pada kelompok ibu hamil yang sebelum melakukan senam hamil yaitu 128x/menit dan setelah diberikan senam hamil detak jantung janin yaitu 133x/menit dan detak jantung janin pada kelompok ibu hamil yang tidak melakukan senam hamil yaitu 149x/menit. Hasil uji $\mathrm{T}$ Dependent didapatkan nilai $P$-Value $0,000(<0,05)$. Maka dapat disimpulkan bahwa ada pengaruh senam hamil terhadap detak jantung janin pada kelompok yang diberikan perlakuan senam hamil di wilayah kerja Puskesmas Kuta Baro Aceh Besar. ${ }^{8}$ 
Hasil penelitian ini juga sejalan dengan penelitian yang dilakukan oleh peneliti sebelumnya yaitu pengaruh pemberian senam hamil dengan detak jantung janin pada ibu hamil trimester II di wilayah kerja Puskesmas Samata Kabupaten Gowa dengan jumlah sampel 36 ibu hamil. Hasilnya rerata detak jantung janin sebelum dilakukan senam hamil yaitu 146x/menit dan rerata detak jantung janin sesudah dilakukan senam hamil yaitu 141x/menit. Hasil uji $\mathrm{T}$ berpasangan didapatkan nilai $P$-Value 0,011(<0,05). Maka dapat disimpulkan bahwa ada pengaruh senam hamil terhadap detak jantung janin setelah dilakukan senam hamil di wilayah kerja Puskesmas Samata Kabupaten Gowa. ${ }^{9}$

Senam hamil adalah latihan yang mempersiapkan ibu hamil secara fisik dan mental dalam menghadapi persalinan. ${ }^{10}$ Senam hamil adalah latihan jasmani yang bertujuan untuk menambah elastisitas otot panggul, relaksasi, memperbaiki sikap tubuh, dan mengatur kontraksi serta mengatur teknik pernapasan. Oksigenasi jaringan janin terawat selama latihan senam hamil yang ditandai dengan detak jantung janin yang melambat tetapi teratur dan kuat. ${ }^{11} \mathrm{Ibu}$ hamil yang melakukan senam hamil secara rutin maka jantung akan bertambah kuat dan jika jantung sudah leboih kuat, detak jantung janin akan menurun. Maka, jantung tidak perlu bekerja terlalu berat untuk mengompa darah. ${ }^{6}$

\section{KESIMPULAN}

Berdasarkan hasil penelitian Pengaruh Senam Hamil Terhadap Detak Jantung Janin didapatkan kesimpulan yaitu:

a. Ibu hamil yang mengikuti senam hamil berjumlah 16 responden melakukan senam hamil sebanyak 4 kali dan 16 ibu hamil tidak mengikuti senam hamil.

b. Ibu hamil yang menjadi responden pada penelitian ini usia kehamilan mininum yaitu usia kehamilan 28 minggu dan usia kehamilan maxinum yaitu usia kehamilan 33 minggu. Rata-rata usia kehamilan pada penelitian ini yaitu \pm 31 minggu.

c. Usia ibu hamil minimum pada penelitian ini yaitu berusia 17 tahun dan usia maxinum yaitu berusia 42 tahun. Rata-rata usia ibu hamil pada penelitian ini yaitu \pm 30 tahun.

d. Pendidikan terakhir ibu hamil yang menjadi responden penelitian yaitu SD 25,0\%, SMP 31,3\% dan SMA 43,8\%. Paling tinggi pendidikan terakhir ibu hamil yang responden yaitu SMA berjumlah 14 responden dan pendidikan terakhir ibu hamil yang paling rendah yaitu SD berjumlah 8 responden.

e. Ibu hamil yang bekerja baik bekerja sebagai pedagang adan asisten rumah tangga pada penelitian ini berjumlah 13 responden (40,6\%) dan ibu hamil yang tidak bekerja 
atau hanya IRT saja berjumlah 19 responden $(59,4 \%)$

f. Nilai $p$-value pada pengaruh senam hamil terhadap detak jantung janin yaitu 0,000 (<0,05). Hasil ini menunjukkan terdapat pengaruh senam hamil terhadap detak jantung janin.

\section{DAFTAR PUSTAKA}

Asriah, Gustiana.2015. Pengaruh Senam Hamil Terhadap Detak Jantung Janin Pada Ibu Hamil Trimester III Di Wilayah Kerja Puskesmas Kuta Baro Aceh Besar. Banda Aceh Jurnal Kesehatan Ibu Hamil. Diakses pada tanggal 26 September 2017.

Gondo,Kurniawan. 2016. Asuhan Kebidanan Bayi Baru Lahir. Jakarta: Salemba Medika.

Khumaira. 2015. Ruang Lingkup Kehamilan. Jakarta: PT.Bina Pustaka.

Mutmainnah, Rina.2016. Pengaruh Pemberian Senam Hamil Terhadap Detak Jantung Janin Pada Ibu Hamil di Puskesmas Samata Kabupaten Gowa, Skripsi, Program Studi Fisioterapi Fakultas Kedokteran Universitas Hasanuddin, Makassar.
Sastroasmoro,Sudigdo. 2014. Dasar-dasar Metodologi Penelitian Klinis, Jakarta: Seto.

Tarigan, Ikarowina.2010.Ibu Aerobik Jnatung Bayi Sehat.[internet] http://www.mediaindonesia.com Diakses pada 20 September 2017.

The Washingtonpost. 2008. Exercise During Pregnancy Has Baby Benefits, Too. [internet] http://www.washingtonpost. com/wpdyn/content/article/2008/04/0 8/AR200840801474.html Diakses pada 20 September 2017.

Wagey, Theodarus,Billy. 2012. Senam Hamil Meningkatkan Antioksida Enzimatik Pada Wanita Hamil. Jakarta: Rineka Cipta.

Wahyuni, Candra. 2010, Efektifitas senam hamil dan jalan kaki terhadap keteraturan detak jantung janin pada ibu hamil trimester II dan III di BPM Fatmi Hartati desa Joho Watis. Kediri: Jurnal Kesehatan Ibu Hamil. Diakses pada tanggal 24 September 2017.

WHO. World Health Statistics 2015: World Health Organization; 2015.

Widyanto, Toni .2010.Manfaat dan Kerugian Olahraga Pada Kehamilan.[internet] http://kokr.com/topic Diakses pada 27 September 2017.

Ready to submit your research? Choose INFOKES and benefit from:

- fast, convenient online submission

- thorough peer review by experienced researchers in your field

- $\quad$ rapid publication on acceptance

- support for research data

- Open Access which fosters wider collaboration and increased citations

- maximum visibility for your research

At Health Polytechnic of Kupang, research is always in progress.

Learn more http://jurnal.poltekkekupang.ac.id/index.php/infokes 